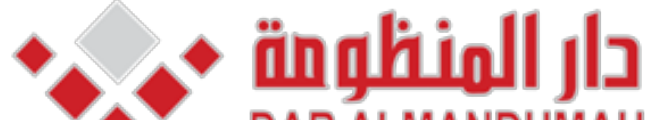 DAR ALMANDUMAH

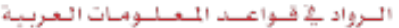

The Secular and Spiritual Duality in Old English and Early Arab Poetry مجلة كلية اللغات والترجمة جامعة الازهر - كلية اللغات والترجمة

Khogeer, Effat Jamil

$3 \varepsilon$

نعم

2012

يوليو

$52-77$

752537

بحوث ومقالات

AraBase

العلمانية، الشعر الإنجليزي، الشعر العربي، العصر القديم http://search.mandumah.com/Record/752537

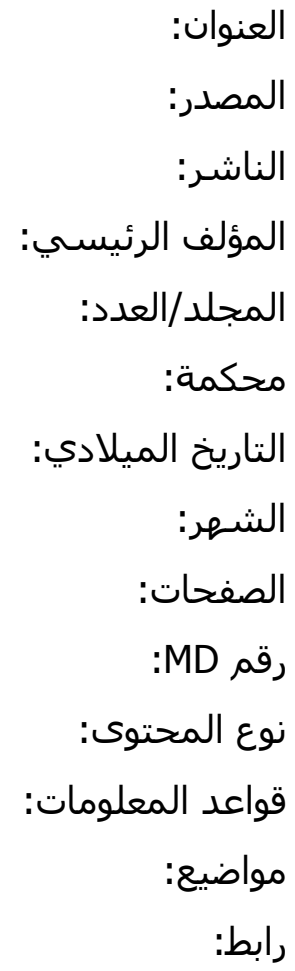

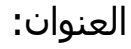

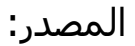

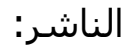




\title{
The Secular and Spiritual Duality in Old English and Early Arab Poetry
}

\author{
By \\ Dr. Afaf (Effat) Jamil Khogeer \\ Associate Professor/ English Literature \\ Department of English, Faculty of Social Sciences \\ Umm Al-Qura University \\ Holy Makkah 21955
}




\begin{abstract}
This literary study will present some examples of Old English and early Arab poetry that combines both a secular and spiritual duality in the various aspects of the poets represented from the $6^{\text {th }}$ to $12^{\text {th }}$ centuries. The selected old English poetry of the $7^{\text {th }}$ to $11^{\text {th }}$ centuries is from the only four existing manuscripts of this era: the Exeter Book, the Junius Manuscript, the Vercelli Manuscript, and The Beowulf Manuscript, or Cotton Vitellius. The selected Arab poetry is from the $6^{\text {th }}$ century pre-Islamic era known as Jahiliyyah to the $7^{\text {th }}-12^{\text {th }}$ centuries after the emergence of Islam. The sources of the selected Arab poetry are the seven known qasida, or long odes, in a collection known as the $M u$ 'allaqaf (the hanging poems) compiled by Hammad al Rawiya and collections of members of elite families and royal courts. The Old English and early Arab poetry reveal the use of many secular images that invariably are connected to the religious values that were part of the moral codes of Islam and Christianity.
\end{abstract}

\title{
Introduction
}

The paradoxical relationship between secular living and the struggle for a spiritual voice comes through in the way that poets influence the societies they live within. Often, the nature of poetry could provide insight into how the people lived under a secular or theocratic style of government, defining the debauchery and crude ways of life not seen much through the religious dogma of poetry geared toward religion. This literary study will present some examples of Old English and early Arab poetry that combines both a secular and spiritual duality in the various aspects of the poets represented from the $6^{\text {th }}$ to $12^{\text {th }}$ centuries. 


\section{Old English: $7^{\text {th }}$ to $11^{\text {th }}$ Centuries}

In the Old English period, the original language spoken in England was enriched by German, Latin and Norman influences. The Anglo-Saxons dominated English culture and the oldest surviving poems are Anglo- Germanic. Old English verse came down to the English from their Germanic forefathers. It is "exotic to the modem eye, it works rather like pearls from the deepest and most remote of oceans. It speaks of a world, social, martial and religious" (Strachan \& Terry 15). The poetry exists in only four manuscripts: the Exeter Book, the Junius Manuscript, the Vercelli Manuscript, and The Beowulf Manuscript, or Cotton Vitellius. All of these manuscripts are dated from about 100 and are written in AEfric, a West Saxon dialect. The Church monopolized the production of manuscripts. A layperson might know how to read; he/she might even be an author (like King Alfred). But it would hardly occur to him/her to undertake the work of a scribe, any more than it would occur to the ordinary reader or author of today to undertake the work of a printer. The making of manuscripts was in the hands of the Church because the art or craft of writing on parchment with pen and ink was part of the professional equipment of the welltrained cleric, and of him alone. And the monopoly was strengthened by the workings of supply and demand:

The works are steeped in the fantastic while including elements of the newly accepted and fairly popular religion of Christianity. In a land as bleak and isolated as England, it is easy to see how a religion that provided a sense of hope would be adopted into both the previously pagan culture and the literature. (Lambdin \& Lamb din. 1)

"Death Song of the Venerable Bede" 
One of the most famous pieces of Old English pious poetry is the "Death Song of the Venerable Bede" (d. 735), preserved by having been quoted in the Epistola Cuthberti de Obitu Bedae. The modem rendering which follows is based on the text of the Epistola found in MS St. Gall 254:

Before the unavoidable journey there, no one becomes

wiser in thought than him who, by need,

Ponders, before his going hence,

What good and evil within his soul,

After his day of death, will be judged. (Baugh 44)

This five-line poem of a single sentence evidently belongs to the classical, not the pre-classical style of composition. The thought as it stands is Christian, and Bede had Doomsday in mind. Yet the point of view needs but a slight shift to give words that would befit Bede's pagan forefathers, who prized above all else that a good name after death may be had by living worthily, and not otherwise. The pagan way of praising a person instead of God is present in this poem.

Cynewulf: "The Fates of the Apostles "

Nearly all Old English poetry is anonymous. One poet, however, had a habit of signing his verses, and from these signatures his name is known: Cynewulf. The earliest possible time for Cynewulf is the first part of the ninth century. Little is known of him, only what is known is gleaned from his work. One of his poems, "The Fates of the Apostles," consists of 122 lines, recorded in the Vercelli Book 2 (late tenth century). It falls into two parts: the list proper, in which are named the places or countries where the twelve apostles taught and died; and the poet's signature with accompanying verses (Krapp 4-6). A 
certain learned, antiquarian spirit also enters in, and such a list, though without dates, obviously had practical (didactic) worth besides. Cynewulf starts the poem by telling us he "gleaned far and wide" how the apostles "made their virtue known," and one naturally infers that the poet made a compilation drawn from various sources. His signature is embedded in the poem, making it a sort of riddle:

Wealth (F) shall be at it end there. Men enjoy this on earth, but not for ever will they be allowed to remain together: abiding in the world. The pleasure (W) which is ours (U) in this native place will fail and then the body's borrowed fineries will crumble away, even as the sea $(\mathrm{L})$ will vanish away when the fire $(\mathrm{C})$ and trumpet $(\mathrm{Y})$ exercise their strength in the straits of the night; coercion (N) will lie upon them - their thraldom to the King. (Krapp 14)

Cynewulf's motive for singing his name was not vainglory; instead, he hoped that those who liked his poems would name him in their prayers. According to Krapp, "the motive which inspired its composition was, therefore, purely literary and devotional" (xxxii).

Elegies

The brief Old English elegies are lyrics that form a group similar in theme and tone. The speaker, whether the author or a fictional persona, sings of loss, grief, and, above all, exile. The two most famous, and most frequently translated and anthologized, elegies are "The Wanderer" and "The Seafarer," compositions of unusual poetic power and beauty. The authors' names and where they lived are unknown. The Wanderer poet puts most of his verses in the mouth of a kemp (the wanderer) 
made homeless by the death of his lord. The wanderer may be described as an old soldier turned sage. His dearly bought wisdom takes two main forms: (1) gnomic sayings, and (2) reflections on the transitory nature of all earthly things (Greenfield 2000).

In "The Wanderer," the loss lamented is that of a lord, because of which the speaker is in exile. He says movingly, "I've drunk too many lonely dawns, / Gray with mourning" (Greenfield 215). Although he lamented the loss of a lord, he turns to God for consolation: "It's good to find your grace in God, the heavenly rock/ where rests our every hope" (Greenfield 215). The poem is a reminder that, "life and fame are fleeting. The human condition of mutability, a change rarely for the better, is consistently displayed" (Lambdin \& Lambdin 7).

"The Wanderer" contrasts the cold and friendlessness of the sea to the warmth and fellowship of land in the company of a generous lord. "The Seafarer" acknowledges the same opposition. However, this speaker chooses to go on sea voyages, and his "soul roams with the sea" (Cameron 59). He has chosen voluntary exile from society in order to save his soul: "Thus the joys of God are fervent with life, where life itself fades quickly into the earth" (Cameron 64-66). The call of the sea in this poem is a call to suffering, toil, privation. Only by denying oneself here can one win salvation hereafter. The characters respond that the call of the ocean is the call of God; "clearly the implication here is the ideation that the path to heaven is filled with vigorous trials and problems that must be overcome, lest the adventure of life end in tragedy" (Lambdin \& Lambdin 8). Seafaring thus represents and symbolizes the sterner side of the Christian way of life.

Several of the elegies of this era, such as "A Woman's 
Lament," eulogize the loss, not of a lord, but of a loved one. The poem is obviously spoken by a woman. Old English was a language that had grammatical gender, and the endings used in "A Woman's Lament" (geomorre, "mournful," and minre sylfre, "my own self') indicate that the speaker is female (Treharne 7678).

This song of journeys into sorrow

Is mine. I sing it. I alone

Can ravel out its misery, full-grown

When I was, and never worse than now.

The darkness of exile droops on my life.

His going began it, the tossing waves

Taking my lord. I was left in the dawn

Friendless where affection had been. I

travelled

seeking the sun of protection and safety,

Accepting exile as payment for hope. (Treharne 77)

The voices in "A Woman's Lament" reflect the same type of language used by the "Wanderer" and the "Seafarer," speaking of "the darkness of exile" with secular instead of religious overtones (Treharne 76).

Beowulf

Old English poetry's greatest monument is Beowulf, the story of prince Beowulf and Grendel, the monster. Beowulf displays Anglo-Saxon characteristics in a clear fashion, including the ever-present quest for fame. This pursuit fuels his actions and each victory, only typical of Anglo-Saxon behavior. 
Written in a pre-Christian nation in northern Europe between the seventh and tenth century, Beowulf reveals many characteristics of society at that time. More striking is the originality of Beowulf in structure. By treating in full two chapters only of Beowulf s career, the poet makes his tale marvelously simple. The elaboration not only lends richness and variety to the action, but also makes the hero and his deeds part of the age in which he and they are set, "with its remarkable mythological terrain of dragons and other grotesquerie, we see a striking fusion of Germanic folktale and Christian apologetics" (Strachan \& Terry $15)$.

Since the scene in Beowulf is laid in Scandinavia, most of the allusions and episodes deal with Scandinavian history and story, but other quarters of Germania are brought into the picture as well. Eormenric and Hama stand for the east. The allusions to the fall of Hygelac, and the Finn and Ingeld episodes, serve to link north and west. The association of Sigemund with Heremod, and the connection of both with Beowulf himself, have a like function, while Offa, the representative of the Angles (the poet's own tribe), though introduced by a tour de force, symbolizes the unity of ancient Germania. In these and other ways the poet rises above mere story-telling; he brings before the whole world, the heroic age of his forefathers. In the poem, secular and religious elements are ambiguous:

Disagreements over the Christian-versus-secular emphasis typically arise whenever Beowulf 's motivation or attitudes are scrutinized. Most readers sense that anachronistic Christian values are meant to clarify Beowulf 's judgment, but for others an unyielding ambiguity always seems to qualify his virtue. Beowulf especially seems to succumb to pride (or its Germanic 
equivalent), a notorious vice inimical to Christian humility. (Gwara 1)

The greatness of Beowulf lies largely if not chiefly in its wording. In Beowulf the theme is secular, the treatment involved and sophisticated, bookish rather than popular:

The poem is extremely valuable in its explicit views of the harsh and pagan lives it explores. The protagonists and supporting characters display undying faith in wyrd (fate), which is clumsily integrated with the Christian belief that man should have faith only in God and his grace. (Lambdin \& Lambdin 4)

The Anglo-Saxon culture had a history of aggression, with its society centered on this aspect. Indeed, the Anglo-Saxons first conquered the local Britons and established its own culture with a distinct code of faine - the ultimate goal of being a glorified warrior- since the populace did not believe in an afterlife. Warriors were solely concerned with how the name is represented once they die by becoming the best warrior in the battlefield. The effects of this cultural background provide the central plot for Beowulf and define the motivation for all of his heroic actions (Strachan \& Terrry 13-21).

The idea of manliness /heroism and the Anglo-Saxon culture is meticulously represented in Beowulf, extremely obvious through his actions. Indeed, the whole book focuses on the plotline of a hero defeating monsters and evil. Beowulf's hunger for glory motivates and inspires him to reach great heights, a trait only too familiar to Anglo-Saxon beliefs and values at the time. In describing the younger Hrothgar, the text states, "The fortunes of war favoured Hrothgar./ Friends and kinsmen flocked to his ranks,/ young followers, a force that 
grew/ to be a mighty army" (Heaney 64-67). This passage reflects the fact that society at this time appreciated strong warriors, a path to definite power. Obviously, Beowulf tries and succeeds in reaching this ideal by attempting to defeat monsters that threaten both the Danes and the Geats. After Beowulf defeats Grendel, Horthgar proclaims that "I have often honoured smaller achievements/ recognized warriors not nearly as worthy/ lavished rewards on the less deserving./ But you have made yourself immortal by your glorious action. " (Heaney 950954). This tremendous feat causes Beowulf to become eternally glorified and revere. The everlasting search for fame and the glorious rewards that can be acquired drive Beowulf to take on such monstrous creatures, thus creating the main story of Beowulf and aligning it to Anglo-Saxon traditions.

Additionally, Beowulf exhibits bravery, a trait that the Anglo- Saxons not only emphasized, but highly respected. Beowulf takes up the challenge of defeating three monstrous creatures that would make others cower in fear because no one has been able to stand up to the terrors of Grendel and later, the dragon. Hrothgar asserts that most other men would show false bravery when they "would pledge themselves to protect Heorot/ and wait for Grendel with whetted swords. I But when dawn broke.../ over each empty, blood-spattered bench,/ the floor of the mead-hall.../ would be slick with slaughter./ And so they died... and my following dwindled" (Heaney 482-488). Beowulf, in contrast, comes to the rescue, in typical Anglo-Saxon fashion, and actually does something about it by first making a boast and attempting to reach his goal. Beowulf states that "Then news of Grendel/ hard to ignore, reached me at home:/ sailors brought stories of the plight you suffer/ in this legendary hall, how it lies deserted/ empty and useless once the evening light/ hides itself 
under heaven's dome" (Heaney 409-414). He continues to announce his intention of fighting and defeating Grendel, a task that he ultimately accomplishes. Towards the end of Beowulf's life, he demonstrated exemplary bravery when, knowing his own frailty due to age, he nonetheless decides to challenge the dragon that had been ruthlessly ravaging his country. Beowulf senses his mortality when he says that "He was sad at heart/ unsettled yet ready/ sensing his death./His fate hovered near, unknowable but certain:/ it would soon claim his coffered soul, part life from limb." (Heaney 2419-2423). Despite this, he accosts the dragon, which ultimately claims his life. Undoubtedly, Beowulf displays valiance through his actions that the Anglo-Saxon culture would regard as admirable.

However, Beowulf's concern for others more than selfish personal desires remains nonconforming to the Anglo-Saxon culture. Generally, Anglo-Saxons tended to be a group of people striving for personal fame, name, and riches. Beowulf's actions indicate otherwise. In the Anglo-Saxon culture, bravery and glory are rewarded with treasures and riches. Hrothgar follows through with his promise of giving Beowulf lavish treasures following the defeat of Grendel and Grendel's mother, yet Beowulf does not solely keep these to himself. Beowulf presents his treasure to King Hygelac- "These, King Hygelac, I am happy to present/ to you as gifts... Enjoy them well" (Heaney 2148-2149)—and proceeds to present Queen Hygd with a priceless gorget Beowulf has already assured his name will forever be remembered with his slaughters of Grendel and Grendel's mother, so his selfless contributions to others deem his actions truly charitable instead of simply a preplanned act of further his own interests. His people extol his life as "a man most gracious and fair-minded,/ kindest to his people and 
keenest to win fame" (Heaney 3181-3182) because even though his fate was certain, Beowulf-unlike Hrothgar, who selfishly decided to shirk his leadership responsibilities and weakentried to protect his people by challenging the vicious dragon and taking action. It would have been all too easy for him to emulate Hrothgar and save his own life, yet Beowulf's character forces him to take action. His people view and admire him in extremely high regard as a genuinely remarkable king who truly cared for the well-being of his people rather than for purely wealth and gold

Furthermore, the monk vividly depicts Beowulf as trying to distance himself from the societal norms of his culture by hinting that violence only creates a never-ending cycle of senseless bloodshed. In the Anglo-Saxon culture, the whole concept of war as blood feuds occurs only too commonly. In the backdrop of the main events in Beowulf a constant recurrence of tales of war and bloodshed exist. For instance, after Beowulf $\mathrm{s}$ death, Wiglaf predicts the future of the Geats and recounts their history with competing clans, including the neighboring Swedes. Wiglaf sorrowfully relates, "Nor do I expect peace or pactkeeping/ of any sort from the Swedes. Remember: / at Ravenswood, Ongentheow/ slaughtered Haethcyn" (Heaney 2922-2925) and continues to expand on the history of their feuding. After Beowulf s death, he predicts, these enemies will seize this opportune time of weakness to attack and attain revenge. However, unlike the rest of his society, the monk portrays Beowulf as opposed to how a death leads to countless more deaths because of revenge, creating a continuous cycle of everlasting carnage. The story about how the last survivor of a long forgotten race had written "Pillage and slaughter/ have emptied the earth of entire peoples" (Heaney 2265-2266) pleads 
the case that contrary to the Anglo-Saxon message of continual wars, wars distinguish race and only useless treasures are left.

After Beowulf s arrival at his homeland, he foresees the consequences of a marriage between Freawaru and Ingeld. He predicts that even a woman is not only to make peace through previous histories of bloodshed; Beowulf states, "But generally the spear/ is prompt to retaliate when a prince is killed, / no matter how admirable the bride may be" (Heaney 2029-2031). Through his foreshadowing of the gruesome events to come because of historical animosity between the two tribes, the monk implicates that Beowulf is indeed wary of how hostilities lead to only more conflicts. The monk portrays Beowulf as seeking to renounce the endless phase of violence that so defines life in an Anglo-Saxon society.

Without a doubt, Anglo-Saxon characteristics are critical to both the plot and the setting of Beowulf. While these characteristics do influence Beowulf s actions, Beowulf also exhibits actions different from the archetypal Anglo-Saxon warrior. These two opposing forces contrast to form a fairly moving Beowulf and helps mold his personality. Moreover, these customary and non-traditional effects create a dynamic storyline with forces that value strength in the human nature in addition to accentuating the importance of generosity and magnanimity in spirit.

The Norman invasion in 1066 marked the end of the Old English period and the beginning of the Middle English period. During the Old English period, "Many pagan thoughts had to be supplemented gently to appease the general populace in this transition to a Christian society" (Lambdin \& Lambdin 10). Each of the Old English poets regarded their work as a process of discovery; there was a vital experience with roots, more or less 
obscure, in their own experiences which had to be brought into clarity and full meaning. Thus the poems represent their efforts to make sense of their world. Their efforts to write the poems are closely parallel to the readers' efforts to make sense of their own process of daily living.

Early Arab Poetry: $6^{\text {th }}$ to $12^{\text {th }}$

Centuries

\section{Pre-Islamic Poetry}

The era before the emergence of Islam and Prophet Muhammad -may peace be upon Him- in the $7^{\text {th }}$ century is known as the Jahiliyya. The Semitic tribes that inhabited the Arabian Peninsula consisted of the nomadic Bedouin tribes, who lived a wandering sheepherding and goat herding existence, and the settled Hejazi who were farmers and traders, living in settlements and cities. Pre-Islamic Arabian tribal groups were governed loosely through the election of a sheik, the leader of the tribe. They embraced animistic religion that maintained no assertion of life after death, and adhered to tribal rituals that reinforced their ethics of bravery, pride, family loyalty, and revenge (Lewis 256-30).

During the pre-Islamic period, poets had a significant role in the predominantly tribal society of Arabia:

In the centuries before Muhammad came to unite them into a nation, The Arabs were living as separate tribes, and in the condition of tribal life the poet enjoyed a high status. He was considered as gifted with supernatural powers and thus he became the oracle of the tribe, their guide in peace, and their champion in war. (Chaitanya 31)

One important ritual of the pre-Islamic Arab culture was each tribe's journey to the city of Makkah for the annual Ukaz 
fair. During the fair, they had poetry contests each day for a month, and the best poems were selected and hung in the Ka'ba, which housed the statues of the gods for each local tribe. The seven known qasida, or long odes, of this type are in a collection known as the Mu'allaqaf (the hanging poems) compiled by Hammad al Rawiya (c. 775). These poems are the high moment of Arabic poetry and a rare window into Bedouin life (Lewis 201-22).

Although, like some of the Old English poetry, the $M u$ 'allaqat were poems of an oral tradition that were preserved through a class of poem reciters called Rawis, who accompanied the poets, memorized the poems, and kept the tradition alive. Labid ibn Rabiah's "Ode of Labid" is one of these poems. This poem depicts the nomadic lifestyle of Pre-Islamic Arabia with its emphasis of tribal connections and oral traditions. The depictions of the nomadic lifestyle of Pre-Islamic Arabia are frequent throughout the poem.

The poets of the great "hanging poems" received a high honor in their respective tribes. The "Golden Ode of Labid" has all the important parts of a great hanging poem. There is a lost of a beloved, a journey, and a return home with a great feast. It is through hanging poems, such as this one, that the tribes were able to pass on important values to the next generation. The values demonstrated in the poem are honor, trust, and the importance of the tribe (Polk 2-4).

In the beginning of the poem the narrator in his search for his lost love describes how "They stirred a longing in you as they packed up their howdahs" (Polk 5). The howdahs, a carriage on the camels, represented the nomadic lifestyle of the region. In the poem, the narrator's love one's tribe had moved on to find more water and grazing land for their cattle. When this 
campsite was abandoned his love moved with her tribe. He describes a sense of longing for her and this longing leads to a journey. He asks, “But why recall Nawar? She's gone. Her ties and bonds to you are broken" (Polk 5). He searches mountains and valleys and travels across the desert, but he cannot find his lost love. He says, "Cut the bond with one you cannot reach!" (Polk 5).

The traveler has searched the desert for his loved one, when he cannot find her he returns home on his camel. The camel is described in great detail because of its importance in the Arab society. He speaks of his "journey-worn mare" and how they are "surviving on dew" (Polk 6). The camels and lack of water further illustrate the nomadic lifestyle in the Arab region. He has finished his journey through the desert and is ready to return to his tribe.

The poem depicts the narrator's reunion with his tribe and its importance. The camp of the tribe is described as a "closewalled gorge hidden in dust" (Polk 8). There is a sense of homecoming for the weary traveler. There is a moment when he is standing at the top of the valley and looking down at his tribe. This moment signals the end of his journey. He says "I drove her on to the past of an ostrich and faster" (Polk 8). He slaughters his camel for a feast to celebrate his return to the tribe. He says, "From a clan whose fathers have shown the way. For every warrior band there is a guide and a way" (Polk 9). This is important because it describes the sense of loyalty that is given by each member to the tribe. The tribe is life to the people of Pre-Islamic Arabia. The language used in poem demonstrates this connection of tribal life. Respectful words such as "honor" and "trust" are used to describe the tribe (Polk 9).

Other poets like Labid ibn Rabiah utilized the simple 
elements of the desert in their poetry to create fierce, passionate, and simple poems of loss. One of these famous women poets was known as Al-Khansa; her full name was Tumaqdir bint Amr ibn al Harigh ibn al Saharid, She was considered the finest elegiac poet of Arabia. Her work consists of elegies for fallen warriors including her two brothers, Sakhr and Mu awiyah, and four of her sons Yazld, Mu awiyah, Amr, and Amrah, who died at the Battle of al- Qadisiyya. Later in life, Al-Khansa lived in Medina and she and her four sons converted to Islam. She lived near Prophet Muhammad -may peace be upon Him- who is said to have liked her poetry (Arberry 14-17).

Al-Khansa's elegy for her brother Sakhr illustrates her extraordinary ability to evoke emotion and compassion in her writing:

Oh my eyes, be liberal with flowing tears

And weep for the most wonderful protector of rights;

The leader of a people, noble in generosity And bom of a pure lineage.

When the news of his death reached me, I said, -

And people were vocal about the secret talk - My brother, you have departed from us.

And a barrier against visiting you had set in.

Many a benefit -you used to bestow

Upon families and little orphans;

Many a favor you have granted ;

To those securely locked up in captivity! 
May my people ransom the one whose bones Have been forsaken to shine in the soft ground:

The victim of sharpened lances which are

Like the lightening which shines within the camps

Whoever wishes to weep over a great leader any day.

Let him weep for him (Sakhr) with hot tears. (Arberry 38)

Al-Khansa's elegies have the same aspects found in the Old English elegies, "The Wanderer," and "The Seafarer." These elegies measure out the distance between emotion and convention, between local disruptions of bereavement and long traditions of resignation. They follow a pattern of expressing endless grief, praising the fallen man's bravery and generosity, questioning who can fulfill his role as protector and benefactor, and expressing a need for bloody revenge.

Secular and Religious Duality

After the emergence of Islam, the blending of the secular and religious roles for poetry is expressed through the way that the elite families and royal courts interpreted poetry in the $9^{\text {th }}$ and $10^{\text {th }}$ centuries:

Similarly, the poet Artah ibn Suhayyam when asked by the Umayyad caliph 'Abd Allah ibn Marwan, "Will you compose poetry today?" replied, "By God, I am neither sad nor angry, nor drinking, nor desirous of anything, and poetry is composed in one of these (states). (Meisami 27)

This provides a deeper context for the meaning of poetry, especially how it defines the many roles that it takes when influencing the way that Arabic culture functioned as a religious state. Certainly, the common notion of Islam being a religious 
and strict type ideology of codes and values is one that was a constant work in progress during the 9 th and $10^{\text {th }}$ centuries. The need for a poetry that expressed the common problems of the people was a popular way for poetry to reflect the common religious tenets within the Qur'an, as well as to provide a social context in which people could understand and manage their fallibilities - through drinking, desire, lust, etc. These facets of poetry are clearly defined in how the social values often clashed with the religious values that were working in collusion with another during the Old English times in England previously discussed as well as the pre-Islamic era in Arabia.

Secular desires and feelings were reflected in the way that leaders of the various Islamic empires challenged their moral codes. Although there are not many existing examples of poetry that define the secular nature of the common poet of this era of Islamic literary development, the examples set forth by the members of elite families and royal courts serve as the type of poetry that influenced Arabic culture. "The Sultan Saif

Addaulet" is one example of this style of poetry, as it defined the troubles the sultan of Aleppo had with his mistress and of the resulting spiritual struggle to come to terms with his sexual desire:

I SAW their jealous eyeballs roll,

I saw them mark each glance of mine;

I saw thy terrors, and my soul

Shared every pang that tortured thine.

In vain, to wean my constant heart,

Or quench my glowing flame, they strove:

Each deep-laid scheme, each envious art, 
But waked my fears for her I love. (Meisami 27)

This aspect of the sultan's romantic pains are the result of the many "eyeballs" and "glances" from his many jealous wives that push him further into desiring a woman whom he cannot have. These types of confessional poems dictate the desires of the Sultan to find and love a woman that is impossible to have. This type of poetry had a big influence on the way that royalty expressed their personal feeling and desires, even when it was their duty to uphold and impart the strictest moral and ethical standards that a Sultan would have to embody as a ruler. This was a major part of the secular formation of poetry which became a pulpier form within royal courts, as the poetry not only dictated the secular struggles of theocratic rulers, but more so the spiritual struggle that went along with desiring a mistress in the case of the Sultan's poem (Meisami 24-26). These verses project the collusion of a spiritual and secular struggle.

During the $11^{\text {th }}$ century the poetry of secular topics was a major part of the influence of Arabic culture, yet the typified religious role of poetry was also a major proponent of imparting Islamic ideals to the masses. In the more common examples of poetry that was constructed by the common people, the rule of sobriety for many Arabs was a moral value that was considerably stricter than that found in other world religions. The theme of drunkenness is often a popular secular image in $11^{\text {th }}$ century Arabic poetry. The poem "Versus of Yezid to his Father, Mowiah, who Reproached Him for his Drunkenness," provides moral and religious tonality in the way the Arabs imbued the struggle with secular and spiritual lifestyles:

MUST then my failings from the shaft Of anger ne'er escape? 
And dost thou storm because I've

quaffed The water of the grape?

That I can thus from wine be driven,

Thou surely ne'er canst think-

Another reason thou hast given

Why I resolve to drink:

'Twas sweet the flowing cup to seize,

'Tis sweet thy rage to see;

And, first, I drink myself to please,

And, next - to anger thee! (Clouston 107)

The struggle to undermine the drunken nature of the young man's father is the source of the ambivalent way that poetry influenced a growing civilization that was expanding rapidly across Africa and into Central Asia. The sense of revenge the son gets by venting his anger at his drinking is the paradoxical tenet of morality that resides within Islamic culture, but also how it tends toward the secular views of drunkenness as a commonality in these poems. This poem reflects the diverse sense of mixed spiritual and secular connotations in society, which greatly influenced how Arabs struggled with these relatively new religious codes brought down to them through the conquests of Prophet Muhammad. This very ambivalence of tonality in poems of the $11^{\text {th }}$ century of this kind reveals the growing and ever-changing values that were part of Islam's expansion across many divergent cultures:

This ambivalence towards poetry in Arabic-Islamic culture is perhaps a result of complex circumstances surrounding the rise of Islam as a worldview, a way of life, and of the Arabs as a new nation whose influence spread from the Arabian 
Continent to North Africa and Spain, and from the Middle East all the way to the borders of China. (Meisami 24)

This is the critical ambivalence that poetry provides in the clash of secular and spiritual tenets of the religion that were often providing various images of lifestyle, along with the common ideological portrayal of a religious life that was to not involve such secular pleasures as drinking or sexual promiscuity. Surely, Arabs struggled in their early rise with this sense of identity within their own culture, as the growing ideology of their religion would have to confront the moral questions that the religion provided within the context of poetry that was secular, relating to the nature of debasement and corruption of the human spirit. This was yet another major reason why secular and spiritual influences are yet another major part of the way that poetry evolved in the $11^{\text {th }}$ century, as the idea of spirituality was often in collusion with the secular troubles that influenced many Arabs through the inspiration of poetics.

\section{Moral and Religious Ideals}

The $12^{\text {th }}$ century begins to bring a far more spiritual obligation to Arabic poetry in the Muslim world, as the growing power consolidation of the Arabs becomes more institutionalized. Although the tenets of poetry still reflected the secular struggles of empire, the premise of Arabic poetry began to take on a more spiritual path as the varying empires began to evolve. The spirituality often found in the natural writing style of religious tracts found in the Holy Qur'an is also part of the way that spirituality was conveyed in the nature poetry of Ibn Khafaja. This style of poetry reflects the growing ideological construct of poetry, as it pertains to the religious tenets of the Andalusian writing methods (Liebhaber 107-22). Ibn Khafaja's nature poetry reflected this spiritually charged aspect of Arabic 
culture:

The moods of natura benigna already known to early 'Abbasid poetry, were reflected in a new type of nature poetry which was developed later by the Syrian school represented by al-Sanawbari...but it was an Andalusian, Ibn Khafaja, who became the Occident's most dedicated nature poet. (Meisami 28)

The popularity of such natural poetry as brought forth by Ibn Khafaja dictates the growing spirituality and metaphysical nature of poetry that was influencing the way that Arabic culture was evolving during the $12^{\text {th }}$ century. Ibn Khafaja's "The Mountain Poem" is an example of nature poetry with spiritual overtones:

No solace of forgetting stopped my tears

I've wept them out on a life bereaved of friends.

How long shall I remain while riders

bidding farewell as one more friendship ends?

How long shall I be shepherd to the stars

with lidless eyes that cannot help but see

Them rise and set and rise as nights burst past

right to the last night of eternity?

So, Lord, have mercy on Thy desperate

Lifting a hand of stone, Thy mountain kneels. (Liebhaber 107-21)

This poem illustrates a growing reliance on religious values in poetic works. There was a lessening of the values of the secular foundation of life that had been a part of the personal and often 
dire struggles with desire and drinking found in earlier Arab cultures.

Arab poets of $12^{\text {th }}$ century era helped to define the expanding role of metaphysical poetry that was affecting and being affected by Islamic expansion into other parts of the world. Spiritual values in the metaphysical poetry were on a growth pattern that was dissolving the old ambiguities about secular and spiritual life found in earlier Islamic poetry. This poetry had higher spiritual principles and was a part of the dominance of the culture of Islam in other parts of the world.

\section{Conclusion}

The body of literature examined in this study relating to Old English and Arab poetry from the $6^{\text {th }}$ to $12^{\text {th }}$ centuries reveals a slow and ambivalent fusion and eventual divergent view of secular and spiritual themes. The Old English and early Arab poetry reveal the use of many secular images that invariably are connected to the religious values that were part of the moral codes of Christianity and Islam. All of the poems tend to spring from the same source within each of the poets. Although they differ in subject or approach, and they vary in excellence or fluctuate in their power to alter the mind or mood or move the heart, the poems take on their authors' qualities, carry their signature, because of one characteristic - the impulse to praise, to love, to call up, and to inspire. 


\section{Works Cited}

Arberry, A. J. Arabic Poetry: A Primer for Students. London: Cambridge University Press, 1965.

Baugh, Albert C. (Ed). A Literary History of England. New York: Appleton- Century-Crofts, 1948.

Cameron, Angus. "Anglo-Saxon Literature." In Dictionary of the Middle Ages. Ed. Joseph R. Strayer. Vol. 1 New York: Scribner, 1982. pp. 274- 288.

Chaitanya, Krishna. A History of Arabic Literature. New Delhi: Manohar, 1983.

Clouston, W.A. Arabian Poetry. Santa Cruz, CA: Evinity Publishing Inc, [1881] 2009.

Heaney, Seamus. Beowulf: A New Verse Translation. W.W. Norton: New York, 2001.

Greenfield, Stanley \& Daniel Gillmore Calder. A New Critical History of Old English Literature. New York: New York University Press, 1986.

Gwara, Scott. Heroic Identity in the World of Beowulf. Leiden, Boston: Brill, 2009.

Krapp, Philip. Andreas and "The Fates of the Apostles. " New York: Ginn \& Company, 1906.

Lambdin, Laura Cooner \& Lambdin, Robert Thomas (Editors). Companion to Old and Middle English Literature. Westport, CT, USA: Greenwood Press, 2002.

Lewis, Bernard. Cambridge History of Islam Vol. 2B.: Islamic Society and Civilization. Cambridge: Cambridge University Press, 1977.

Liebhaber, Sam. Al Shanfara and "The Mountain Poem" of Ibn Khafaja. Journal of Arabic Literature, 34, pp. 107-12, 2003.

Meisami, Julie. Structure and Meaning in Medieval Arabic and Persian Lyric Poetry: Orient Pearls. New York: Routledge, 2002 
Polk, William, (trans). The Golden Ode by Labid Ibn Rabiah. Chicago: University of Chicago Press, 1974.

Sells, Michael. Ode of Labid. Middletown, CT: Wesleyan University Press, 1989.

Trehame, Elaine, ed. "The Wife's Lament. " Old English and Middle English C.890-C.1400. Oxford: Blackwell, 2001.

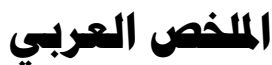

$$
\begin{aligned}
& \text { ازدواجية العلمانية والرومانية * في الشمر الإنهايري } \\
& \text { والهربجي القدبمث }
\end{aligned}
$$

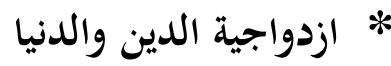

$$
\begin{aligned}
& \text { د /عفاف (عفت) جميل خوقير }
\end{aligned}
$$

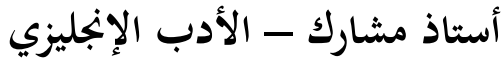

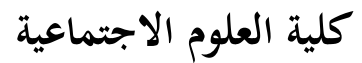

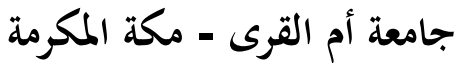

$$
\begin{aligned}
& \text { باعتمادها علي مختارات من الأدب الإنجليزي والعربي القديم ستقوم هذه الدراسة }
\end{aligned}
$$

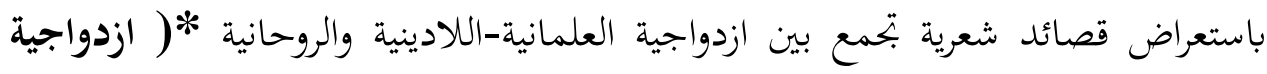

$$
\begin{aligned}
& \text { الدين والدنيا) عند مختلف شعراء من القرن السادس إلى الثاني عشر الميلادي .القصائد }
\end{aligned}
$$

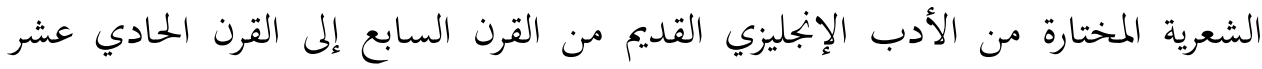

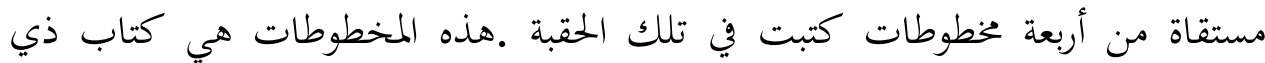

$$
\begin{aligned}
& \text { إكستر، و مخطوطة جونيوس، و مخطوطة فيرسيللي، ومخطوطة ذي بيوولف أو كوتون } \\
& \text { فيتيليوس .على صعيد آخر، فقد تم اختياره قصائد شعرية عربية من حقبة ما قبل الإسلام في في }
\end{aligned}
$$

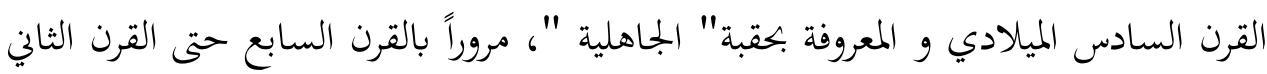

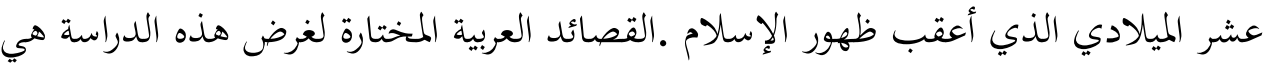

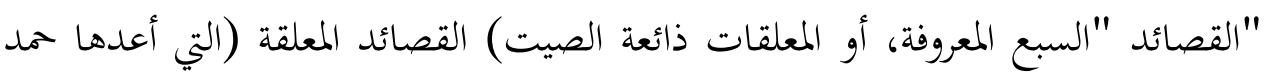


الروية، بالإضافة إلى قصائد شعرية كتبها أفراد العائلات النخبوية والأوساط الملكية آنذاك . تخلص هذه الدراسة إلى أن الشعر في كلا الأدبين العربي والإنجليزي في تلك الفترة استخدم العديد من الصور العلمانية أو الدنيوية القوية الارتباط بالقيم الدينية التي ظلت تمثّل جزءً من الأمخاط السلوكية الأخلاقية للمسيحية والإسلام.

Afaf (Effat) Jamil Khogeer, Ph.D.

Associate Professor/ English Literature

Department of English, Faculty of Social Sciences

Umm Al-Qura University

P. O. Box 4396

Holy Makkah 21955

E-mail: dreik707@hotmail.com: Cell: (00966)505502574 